Arkhais, Vol. 07 No. 1 Januari -Juni 2016

\title{
PERISTIWA TUTUR DALAM MOCKUMENTARY MALAM MINGGU MIKO
}

\author{
Melissa Eka Hana Putry
}

\begin{abstract}
Abstrak. Penelitian ini bertujuan untuk mengetahui peristiwa tutur dalam MockumentaryMalam Minggu Miko. Penelitian ini dilakukan pada September 2013-Juni 2014dengan fokus peristiwa tutur dalam mockumentary tersebut. Objek penelitian ini adalah Mockumentary Malam Minggu Miko. Metode penelitian yang dipakai adalah metode kualitatif dengan teknik analisis isi. Hasil penelitian menunjukkan bahwa terdapat dua latar tempat yang selalu ada pada tiap korpus yang diteliti, yaitu di rumah Miko dan Ryan serta di mobil. Tiga partisipan yang selalu ada pada tiap korpus yang diteliti, ialah Miko, Ryan, dan Mas Anca. Persamaan maksud dan tujuan dari ketiga korpus yang diteliti adalah menceritakan tentang keseharian Miko, Ryan dan Mas Anca. Persamaan bentuk ujaran pada ketiga korpus yang keseluruhannya berbentuk percakapan monolog ataupun dialog. Bentuk kalimat deklaratif, interogatif, eksklamatif dan imperatif ada dalam korpus. Ragam bahasa yang digunakan adalah ragam bahasa tidak resmi. Instrumentalities yang digunakan pada keseluruhan adegan merupakan jalur lisan dengan ragam bahasa tidak resmi. Terdapat norma berinteraksi pada ruang, yaitu jarak pribadi, sosial dan publik di korpus. Pada bentuk penyampaian ditemukan percakapan monolog, dialog dan percakapan telepon pada korpus yang diteliti. Hal ini menunjukkan bahwa keseluruhan adegan dalam tiga serial Malam Minggu Miko memenuhi syarat untuk menjadi sebuah peristiwa tutur. Total 56 adegan dengan 386 ujaran di 3 korpus berbeda yang keseluruhannya memenuhi syarat adanya SPEAKING. Saran dalam penelitian ini agar masyarakat lebih teliti dalam membedakan mana peristiwa tutur atau bukan.
\end{abstract}

Kata Kunci: Peristiwa Tutur, Komponen Tutur, SPEAKING, Dell Hymes, Mockumentary Malam Minggu Miko

\section{PENDAHULUAN}

Peristiwa tutur adalah terjadinya interaksi linguistik dalam satu bentuk ujaran atau lebih yang melibatkan penutur dan lawan tutur, dengan pokok tuturan, di dalam waktu, tempat, dan situasi tertentu. Pateda mengemukakan peristiwa tutur dengan istilah peristiwa bahasa. Menurutnya, yang dimaksud dengan peristiwa bahasa adalah interaksi linguistik yang melibatkan kontak sosial. Hymes sendiri mengkategorikan peristiwa tutur ke dalam delapan komponen. Kedelapan komponen tersebut saling terhubung satu sama lain. Hymes menyatakan bahwa terdapat delapan komponen peristiwa tutur yang bila huruf-huruf pertamanya dirangkaikan menjadi akronim SPEAKING (Abdul Chaer dan Leonie Agustina, 2010). S dalam SPEAKING adalah Setting and Scene yang berkenaan dengan latar waktu, tempat dan situasi psikologis dalam tuturan. $\mathrm{P}$ adalah Participants yang berkenaan dengan penutur dan lawan tutur dalam ujaran. E adalah Ends yang berkenaan dengan maksud dan tujuan. A adalah Act Sequences yang berkenaan dengan bentuk dan isi ujaran. K adalah Key yang berkenaan dengan cara atau nada pembicaraan. I adalah Instrumentalities yang berkenaan dengan jalur bahasa yang digunakan. $\mathrm{N}$ adalah Norm of Interaction and Interpretation yang berkenaan dengan norma interaksi dan interpretasi. $\mathrm{G}$ adalah Genres yang berkenaan dengan jenis dan bentuk penyampaian.

Dalam tayangan-tayangan yang disiarkan di televisi nasional, banyak terdapat peristiwa-peristiwa bahasa yang luput dari perhatian pemirsa tayangan televisi. Salah satunya mockumentary Malam Minggu Miko yang penuh dengan fenomena-fenomena 
bahasa dan peristiwa bahasa yang dirangkum menjadi satu kesatuan episode. Peristiwa bahasa atau peristiwa tutur ini berfokus pada perilaku-perilaku komunikatif yang tersedia dalam tayangan namun tetap pada bentuk dan fungsi yang terdapat dalam komunikasi. Dalam fenomena bahasa terdapat interaksi yang mengharuskan adanya setting yang berhubungan dengan keterangan waktu dan tempat; topik atau tentang apa yang dibicarakan dalam fenomena bahasa tersebut; dan yang terakhir adalah kode atau ujaran yang dipakai dalam interaksi tersebut. Peristiwa tutur sangat menarik untuk dipelajari dan diimplementasikan pada tayangan yang menarik minat pemirsa televisi. Selain karena menambah wawasan yang lebih tentang tiap komponen peristiwa tutur yang ada di tayangan tersebut, hal ini juga dapat memuaskan rasa ingin tahu pemirsa tentang apa saja hal yang mungkin memperkuat tayangan tersebut untuk menjadi lebih menarik dan betah ditonton berlama-lama.

Fokus kajian dalam penelitian ini adalah peristiwa tutur dengan objeknya yang merupakan tayangan televisi berwujud mockumentary berjudul Malam Minggu Miko. Malam Minggu Miko merupakan tayangan televisi pertama yang menggunakan gaya mockumentary atau dokumentasi berdasarkan script atau naskah. Dengan sampulMalam Minggu Miko, sudah sepatutnya banyak pemirsa televisi yang ingin tahu lebih banyak tentang komponen yang melatar-belakangi tayangan yang sukses mengocok perut pemirsa. Maka dari itu dipakailah SPEAKING grid oleh Dell Hymes sebagai pisau analisis kajian karena metode ini dibagi menjadi beberapa aspek komponen tutur yang sangat cocok untuk menganalisis peristiwa tutur secara lengkap dan detil. Keambiguan aktor dalam Malam Minggu Miko berhasil mengambil perhatian pemirsa untuk menonton lebih lama dan tertawa atau sekedar meringis mengikuti alur cerita yang disajikan. Namun pada akhirnya, pisau analisis yang digunakan hanya metode SPEAKING dari Dell Hymes. Metode SPEAKING adalah syarat yang dicetuskan oleh Hymes untuk memenuhi suatu peristiwa tutur, maka untuk menganalisis peristiwa tutur yang paling tepat adalah menggunakan metode ini karena dibagi menjadi beberapa aspek sehingga analisa menjadi lebih jelas dan detil.

Merujuk pada latar belakang di atas, rumusan permasalahan yang diteliti adalah "Bagaimana peristiwa tutur yang terdapat dalam Mockumentary Malam Minggu Miko?" Dalam sosiolinguistik terdapat kajian tentang etnografi komunikasi. Etnografi adalah kajian tentang kehidupan dan kebudayaan suatu masyarakat atau etnik, misalnya tentang adat-istiadat, kebiasaan, hukum, seni, religi, bahasa (Sumarsono, 2012). Jika etnografi adalah kajian tentang masyarakat atau etnik, maka etnografi bisa diterapkan kepada bahasa masyarakat tersebut. Karena sosiolinguistik lebih mengungkapkan pemakaian bahasa dan bukan struktur bahasa, etnografi tentang bahasa difokuskan kepada pemakaian bahasa dalam pertuturan atau lebih luas lagi, komunikasi yang menggunakan bahasa. Dalam suatu etnografi komunikasi pastilah ada percakapan. Sebuah percakapan baru bisa disebut peristiwa tutur apabila memenuhi syarat dan memiliki komponen peristiwa tutur. Dell Hathaway Hymes menyebutkan ada delapan komponen peristiwa tutur yang apabila dirangkaikan akan menjadi SPEAKING dalam bahasa Inggris atau PARLANT dalam bahasa Perancis. Hymes menyebut enam belas komponen yang perlu diperhatikan ketika terjadi peristiwa bahasa (Pateda, 1994).

Komponen itu adalah setting, latar, yang berhubungan dengan dimensi waktu dan tempat; scene atau tafsiran terhadap situasi; spreker atau pembicara; hoorder atau pendengar; toehoorder atau pendengar-pendengar yang ikut; bron atau sumber; funktie van het taalgebeuren atau fungsi peristiwa bahasa; doeleinden van de participanten atau tujuan pendengar dan para pendengar; vorm atau bentuk ujaran; inhoud atau pesan; toonsoort atau jenis aksen yang menyertai pada pembicaraan; taalveriëteit atau variasi bahasa; kanaal 
atau alat yang dipergunakan; normen voor interpretative atau norma-norma penafsiran; dan terakhir genres atau bentuk penyampaian (Pateda, 1994). Dari keenambelas komponen tersebut yang nantinya akan diklasifikasikan berdasarkan yang mirip dan dikerucutkan menjadi akronim SPEAKING yang hanya berjumlah delapan komponen. Chaer dan Leonie Agustina mengemukakan bahwa yang dimaksud dengan peristiwa tutur (speech event) adalah terjadinya atau berlangsungnya interaksi linguistik dalam satu bentuk ujaran atau lebih yang melibatkan dua pihak yakni petutur dan lawan tutur, dengan satu pokok tuturan dalam waktu, tempat dan situasi tertentu, jadi, interaksi yang berlangsung antara seorang pedagang dan pembeli di pasar pada waktu tertentu dengan menggunakan bahasa sebagai alat komunikasinya adalah sebuah peristiwa tutur (Chaer dan Leoni, 2010).

Pilihan individu dari berbagai alternatif yang mungkin dalam suatu peristiwa bahasa tertentu bisa juga menunjukkan latar belakang keluarga dan minat sosialnya, bisa menidentifikasi dirinya orang dari daerah perkotaan, pedesaan, masyarakat terdidik dan bisa juga menunjukkan apakah dia ingin tampak bersahabat atau ingin menjauh, ingin akrab atau ingin berbeda, ingin superior atau inferior (Abd. Syukur Ibrahim, 1993). Dalam tulisannya yang berjudul "Models of the Interaction of Language andSocial Life', Hymes menjelaskan social units yang di dalamnya terdapat speech community, speech situation, speech event, speech act, speech styles, ways of speaking, dan components of speech.

A descriptive theory requires some schema of the components of speech act. At present such a schema can be only an etic, heuristic input to descriptions. Later it may assume the status of a theory of universal features and dimensions. (Hymes, 1972)

Maksud dari kalimat di atas adalah teori deskriptif membutuhkan beberapa skema dari komponen-komponen aksi pengucapan. Saat ini, skema tersebut hanya bisa berupa masukan etik atau heuristic ke dalam deskripsi. Nantinya, skema tersebut dapat memperkirakan status dari sebuah teori tentang dimensi dan fitur universal. Dalam komponen tutur, Hymes juga menjelaskan pada awalnya terdapat enam belas komponen tutur yaitu message form, message content, setting, scene,speaker or sender, addressor, hearer or receiver or audience, addressee, purpose - outcomes, purpose - goals, key, channels, form of speech, norm of interaction, norm of interpretation, dan genres. As has been shown, the sixteen components can be grouped together under the letters, of the code word SPEAKING: setting, participants, ends, act sequences, keys, instrumentalities, norms, genres. That the code word is not wholly ethnocentric appears from the possibility of relabeling and regrouping the necessary components in terms of the French PARLANT: participants, actes, raison (résultat), locale, agents (instrumentalities), norms, ton (key), types (genres). (Hymes, 1972)

Yang bermaksud seperti yang telah diketahui, keenam belas komponen bisa disatukan bersama menjadi akronim SPEAKING atau Setting, Participants, Ends, Actsequence, Keys, Instrumentalities, Norms, Genres. Dan juga akronim tersebut tidakseluruhnya etnosentris. Tampak dari kemungkinan adanya pelabelan dan pengelompokan ulang komponen-komponen penting berkenaan dalam bahasa Perancis, yaitu PARLANT atau Participants, Actes, Raison (résultat), Locale, Agents (instrumentalities), Norms, Ton (key), Types (genres). Keduanya, SPEAKING dan PARLANT sama-sama berarti waktu dan tempat serta situasi, partisipan, maksud dan tujuan, bentuk dan isi ujaran, cara atau nada, piranti bahasa, norma atau aturan berinteraksi dan jenis atau bentuk penyampaian. Pada akronim itu huruf pertama yakni (S) menandakan setting and scene. Setting dalam bahasa Indonesia adalah latar. Menurut Kamus Besar 
BahasaIndonesia, latar adalah 1. Permukaan; 2 halaman; 3 rata;datar; 4 dasar warna (pada kain dsb); 5 Sas keterangan mengenai waktu, ruang, dan suasana terjadinya lakuan dalam karya sastra; 6 keadaan atau situasi (yang menyertai ujaran atau percakapan); 7 Sen dekor pemandanganyang dipakai dalam pementasan drama seperti pengaturantempat kejadian, perlengkapan, dan pencahayaan.

Sementara Scene atau Suasana adalah 1 hawa; udara; 3 keadaan sekitar sesuatu atau dalam lingkungan sesuatu; 3 keadaan suatu peristiwa. Dapat disimpulkan ini berarti berkenaan dengan persoalan waktu, tempat dan situasi berlangsungnya tuturan. Latar biasanya mengacu pada keadaan fisik, sementara suasana mengacu kepada "latar psikologis", atau batasan budaya tentang suatu kejadian sebagai suatu jenis suasana tertentu (Sumarsono, 2012) Apabila kita mengadakan percakapan di tempat makan, ditempat suatu tempat perbelanjaan atau ditempat keramaian lainnya tentu situasinya berbeda dengan mengadakan pembicaraan pada suatu ruangan, seperti di rumah. Sebagai contoh, dalam peristiwa transaksi atau tawar-menawar sandang di sebuah pasar, seorang pedagang mendadak akan berubah dari cara bertutur yang ramah menjadi sangat ketus terhadap calon pembeli karena mungkin dia amat lambat dan berbelit-belit dalam menawar. (Rahardi Kunjana, 2010)

Huruf kedua pada akronim itu adalah (P) menandai participants. Menurut KBBI, partisipan adalah orang yang ikut berperan serta dalam suatu kegiatan (pertemuan, konferensi, seminar, dsb); pemeran serta. Dapat disimpulkan partisipan adalah orang-orang yang terlibat dalam pertuturan (Sumarsono, 2010). Hal ini mengacu pada para penutur, siapa yang menjadi penutur dan petutur. Antara penutur dan petutur, tentunya saling berinteraksi dan saling bertukar peran. Penutur sebagai pemberi informasi, akan berganti menjadi petutur, dan petutur akan menjadi penutur, demikian seterusnya silih berganti sampai pembicaraaan berakhir. Kemudian huruf ketiga para akronim itu (E) yang menandai ends atau maksud dan tujuan Dalam KBBI, maksud adalah 1 yang dikehendaki; tujuan; 2 niat; kehendak; 3 arti;makna (dari suatu perbuatan, perkataan, peristiwa, dsb). Tujuan adalah 1 arah ; haluan; 2 yang dituju; maksud; tuntutan (yang dituntut). Menurut Hymes dalam buku Sosiolinguistik karangan Sumarsono, Hymes menyebut end, mencakup tujuan dalam angan dan sebagai hasil. Tujuan suatu peristiwa dari sudut pandang guyup tidak pelu serupa dengan tujuan mereka yang terkait dalam guyup itu (Sumarsono, 2012). Jadi ends menunjukkan pada persoalan maksud dan tujuan percakapan atau tuturan. Maksud dan tujuan pertuturan ini, kadang-kadang tergantung pada masing-masing partisipan. Namun demikian, dalam suatu percakapan bukan berarti secara total maksud dan tujuan diadakannya pembicaraaan itu antara masing-masing partisipan berbeda-beda, tetapi pasti ada maksud dan tujuan yang sama.

Selanjutnya pada huruf keempat akronim itu terlihat (A) yang menandai ActSequence. Bentuk pesan dan Isi pesan awalnya disebutkan Hymes sebagai komponenyang berbeda. Bentuk pesan menyangkut cara bagaimana sesuatu itu (topik) dikatakan atau diberitakan. Lain lagi isi pesan, berkaitan dengan persoalan apa yang dikatakan, menyangkut topik dan perubahan topik (Sumarsono, 2012). Jadi, actsequence berarti apa isi ujaran ini berkaitan dengan topik ataupun persoalan apa yangdibicarakan. Bentuk ujaran itu sendiri mengacu pada diksi atau pilihan kata yang digunakan. Bentuk dan isi pesan juga merupakan keterampilan komunikatif yang bervariasi dari budaya satu ke budaya yang lain (Sumarsono, 2012). Huruf kelima pada akronim itu adalah (K) yang menandai Key. Hal ini berarti bagaimana gaya dan penampilan para partisipan dalam menuturkan isi pembicaraan. Apakah mereka menyampaikan secara santai serius atau tampak adanya ketegangan. Nada berkenaan dengan tinggi rendahnya suatu bunyi. Dalam bahasa tertentu bisa bersifat fonemis maupun morfemis, dapat membedakan makna. Dalam 
bahasa tonal, biasanya, dikenal lima macam nada, yaitu nada naik, nada datar, nada turun atau merendah, nada turun naik (nada yang merendah lalu meninggi), dan nada naik turun (nada yang meninggi lalu merendah) (Chaer, 2007). Jumlah nada pembeda leksikal dalam bahasa nada tertentu disebut "rejister nada" dalam bahasa yang bersangkutan (J.W.M. Verhaar, 2001).

Tindak tutur bisa berbeda karena key, misalnya antara serius dan santai, hormat dan tak hormat, sederhana dan angkuh/sombong dan sebagainya. Penandaan key mungkin dengan nonverbal, misalnya dengan kedipan mata, gerak tangan, gerak tubuh, cara berpakaian, dan sebagainya tetapi key juga melibatkan satuan tutur yang seringkali dilupakan oleh analisis linguistik (Sumarsono, 2012). Selanjutnya huruf keenam pada akronim itu adalah (I) yaitu Instrumentalities atau piranti bahasa. Piranti disini termasuk dalam saluran dan bentuk tutur atau ragam bahasa. Saluran mengacu pada medium penyampaian tutur: lisan, tertulis, telegram, telepon, dan sebagainya. Ragam lisan tatap muka berbeda dengan telepon, ragam tulisan telegram berbeda dengan surat (Sumarsono, 2012). Ragam bahasa adalah variasi dari sebuah bahasa menurut pemakai. Hal ini menunjukkan ragam bahasa apa yang digunakan pada percakapan itu. Instrumentalities ini juga mengacu pada kode ujaran yang digunakan, seperti bahasa, dialek, fragram, atau register (Chaer, 2010). Dengan kata lain, kode ujaran yang bagaimana digunakan dalam percakapan atau pertuturan itu. Apakah ragam maupun kode-kode ragam bahasa formal atau non-formal dan sebagainya.

Huruf ketujuh pada akronim itu adalah (N) yang menandai Norm ofinteraction and interpretation. Dalam KBBI, norma adalah 1 aturan atau ketentuanyang mengikat warga kelompok dalam masyarakat, dipakai sebagai panduan, tatanan, dan pengendali tingkah laku yang sesuai dan berterima; 2 aturan, ukuran, atau kaidah, yang dipakai sebagai tolok ukur untuk menilai atau memperbandingkan sesuatu. Hal ini berarti adanya norma ataupun aturan yang harus diperhatikan dalam pertuturan. Bagaimana cara mengemukakan pendapat, menyangkal maupun bertanya yang sopan sehingga tidak menyinggung perasaan petutur. Dalam interaksi sosial diperlukan adanya norma atau aturan. Menurut David A. Karp dan W.C. Yoels (1979) dalam bukunya yang berjudul Symbols, Selves, andSociety: Understanding Interaction, ada tiga jenis aturan dalam interaksi sosial yaituaturan mengenai ruang, mengenai waktu dan mengenai gerak dan sikap tubuh. (Pudjiastuti, 2007). Dalam situasi sosial, orang cenderung menggunakan empat macam jarak, yaitu jarak intim (sekitar $0-45 \mathrm{~cm}$ ), jarak pribadi (sekitar 45-1,22 m), jarak sosial (sekitar 1,22 m - 3, 66 $\mathrm{m}$ ), dan jarak publik (di atas 3,66 m) (Pudjiastuti, 2007).

Lalu setiap masyarakat memiliki makna sendiri tentang waktu yang mengatur interaksi seseorang dengan orang lain. Misalnya pada suatu masyarakat tertentu dikenal adanya istilah ,jam karete ${ }^{e}$. Bagi mereka, keterlambatan kedatangan bus, pesawat, atau kereta api menjadi hal yang biasa. Namun apabila kondisi ini terjadi di negara maju, banyak aktivitas orang menjadi terganggu. Aturan lainnya mengenai gerak tubuh mencakup komunikasi nonverbal (tanpa menggunakan bahasa lisan maupun tulisan) merupakan bentuk komunikasi pertama bagi manusia. Komunikasi ini terkadang disadari atau tidak, digunakan seseorang untuk menyampaikan pesan dalam interaksinya dengan orang lain. Contohnya memicingkan mata, menjulurkan lidah, mengangkat bahu, membungkukkan badan, menganggukkan kepala, mengerutkan dahi, mengangkat ibu jari, dan lainnya.

Semua kaidah yang mengatur pertuturan bersifat imperatif (memerintah) atau maksudnya perilaku khas dan sopan santun tutur yang mengikat yang berlaku dalam kelompok. Walaupun begitu, penjelasan tentang norma interaksi masih memberi peluang untuk munculnya interpretasi terutama jika ada masyarakat tutur lain yang ikut serta dalam 
komunikasi tersebut. Perbedaan cara bertutur dapat menimbulkan interpretasi yang berbeda-beda pada tiap partisipan. Jadi, interpretasi pun memiliki norma dan Hymes mengimplikasikan sistem kepercayaan dari suatu masyarakat tutur. Kemudian huruf terakhir pada akronim itu adalah (G), yakni genre. Richards dkk. (1985) dalam Sumarsono (2012), mengemukakan, di dalam analisis wacana, genre adalah sekelompok peristiwa tutur yang oleh guyup tutur dianggap mempunya tipe yang sama, sebagai contoh: doa, khotbah, cakapan, nyanyian, pidato, puisi, surat dan novel (Sumarsono, 2012). Genre mengacu pada jenis bentuk penyampaian. Apakah bentuk bahasa dalam penyampaian isi pokok pembicaraan dengan menggunakan bentukan narasi, eksposisi, deskripsi maupun argumentasi. Bahkan, apakah berbentuk bahasa sastra seperti pantun, pepatah ataupun melalui sebuah puisi. Hymes menambahkan, genre itu sering terjadi bersamaan dengan peristiwa tutur, tetapi harus tetap diperlakukan berbeda dari peristiwa tutur (Sumarsono, 2012). Keduanya bisa terjadi dalam peristiwa berbeda dan sebuah genre mungkin juga terjadi berulang-ulang dalam berbagai situasi yang berbeda sebagai bagian dari rangkaian tindak tutur berbeda.

Sebuah mockumentary (gabungan dari kata-kata Mock atau mengejek dan dokumenter) adalah jenis film atau acara televisi dimana peristiwa fiksi disajikan dalam gaya dokumenter untuk membuat parodi. Bentuk produksi ini sering digunakan untuk menganalisis atau mengomentari kejadian terkini dan masalah dengan menggunakan pengaturan fiksi, atau parodi dokumenter yang dibentuk sendiri. Mockumentary dapat berupa komedi atau dramatis dalam bentuknya, meskipun bentuk komedi yang lebih umum. Sebuah mockumentary dramatis (kadang-kadang disebut sebagai docufiction) tidak harus sama dengan docudrama, genre fiksi di mana teknik yang dramatis dikombinasikan dengan unsur-unsur dokumenter untuk menggambarkan peristiwa nyata. Mockumentary merupakan subfilm dokumenter. Film dokumenter menyajikanrealita melalui berbagai cara dan dibuat untuk berbagai macam tujuan. Film dokumenter tidak penah lepas dari tujuan penyebaran informasi, pendidikan, dan propaganda bagi orang atau kelompok tertentu (Heru Effendy, 2006). Intinya film dokumenter tetap bepijak pada hal-hal senyata mungkin. Seiring dengan perjalanan waktu, muncul berbagai aliran dari film dokumenter.

Malam Minggu Miko adalah serial komedi yang berbentuk cerita pendek.Durasi film cerita pendek biasanya di bawah 60 menit. (Heru Effendy, 2006). Film Malam Minggu Miko rata-rata berdurasi 10-13 menit saja, itu berarti film mockumentary ini juga merupakan film cerita pendek. Film Malam Minggu Miko dibuat oleh Raditya Dika, dimana selain sebagai pemain utama, ia juga menjadi produser, penulis cerita sekaligus pengarah dalam penggarapannya. Selain Raditya Dika, serial ini juga dibintangi oleh Ryan Adriandhy dan Hadian Saputra. Serial ini merupakan serial komedi pertama di Indonesia yang menggunakan gaya Mockumentary. Tayang mingguan di Kompas TV, terdapat dua episode dalam setiap penayangan, masing-masingnya berdurasi kurang lebih 12 menit. Pembuatan serial komedi ini berawal dari keinginan Dika untuk membuat mockumentary bergenre komedi. Bersama dengan beberapa teman-temannya, Dikamerilis seri pertamanya berjudul Nissa dalam bentuk sebuah webisode di Youtube. Seri pertamanya ditonton hingga ratusan ribu pengunjung. Kemudian diproduksilah seri kedua berjudul Miranda. Sukses dengan dua seri yang ditayangkan melalui Youtube, akhirnya serial Malam Minggu Miko ditayangkan di televisi, tepatnya Kompas TV. Dua episode perdananya yaitu berjudul Hari Penembakan Sasha dan Airsoft Lisa, tayang pada tanggal 10 Desember 2012. Sehari setelah penayangan, episode yang telah ditayangkan akan diupload melalui channel milik Dika dan Kompas TV di Youtube. 


\section{METODE PENELITIAN}

Tujuan penelitian ini adalah untuk mengetahui peristiwa tutur beserta komponenkomponennya yang terdapat dalam serial mockumentary Malam MingguMiko. Penelitian ini difokuskan pada peristiwa tutur dalam Mockumentary MalamMinggu Miko yang ditayangkan dalam Kompas TV. Teknik analisis data menurut Mahsun di antaranya:

1. Reduksi Data, yaitu data peristiwa tutur dapat terjadi setiap hari. Data dari serial Malam Minggu Miko yang telah ditranskripsikan akan dicatat, diseleksi, dan dikelompokkan sesuai dengan data yang relevan. Data yang relevan tersebut mencakup komponen peristiwa tutur dalam Mockumentary Malam Minggu Miko.

2. Penyajian Data, yaitu penyajian data dimaksudkan untuk memahami apa yang terjadi untuk merencanakan analisis selanjutnya. Data komponen peristiwa tutur yang telah didapat dari proses reduksi akan disajikan dalam tabel kerja.

3. Pengambilan Kesimpulan / Verifikasi, yaitu kesimpulan akan menjawab rumusan masalah terkait penggunaan metode SPEAKING pada Mockumentary Malam Minggu Miko dalam bahasa kualitatif yang deskriptif dan interpretatis sifatnya (Mahsun, 2007).

\section{HASIL DAN PEMBAHASAN}

Berdasarkan hasil analisis berikut contoh-contohnya di atas, dibuat sebuah rangkuman data yang menjelaskan hasil analisis secara gamblang. Dalam penelitian Peristiwa tutur dalam Mockumentary Malam Minggu Miko, yang menjadi pisau analisisnya adalah metode SPEAKING milik Dell Hathaway Hymes. Dan yang menjadi objek analisisnya adalah adegan-adegan dalam serial mockumentary MalamMinggu Miko. Mockumentary Malam Minggu Miko adalah suatu tayangan yangtadinya ditayangkan di Kompas TV pada senin malam namun kini masa tayangnya sudah habis dan hanya bisa dinikmati di laman internet youtube. Serial MalamMinggu Miko ditayangkan berupa mockumentary atau Mock Documentary. Denganmodel seperti film dokumenter tetapi naskahnya dibuat, bukan berdasarkan kisah nyata serta filmnya bergenre komedi. Metode SPEAKING sendiri merupakan metode gagasan dari Dell H. Hymes. Seperti yang dikatakan oleh Dell Hymes, suatu peristiwa tutur harus memenuhi delapan komponen tutur yang terdiri dari setting and scene, participants, ends, actsequences, key, instrumentalities, norm of interaction and interpretation and genre yang jika dirangkai huruf pertamanya maka akan berbunyi SPEAKING. Dalam serial Malam Minggu Miko, telah diaplikasikan kedelapan komponen tutur tersebut dalam tiap adegannya. Guna penelitian, diambil tiga korpus sebagai objeknya. Korpus tersebut adalah Episode Nissa, episode Hipnotis Vania dan episode Cinta Kucing Melly.

Dalam korpus satu yaitu Episode Nissa ditemukan 14 adegan dengan 135 jumlah ujaran. Topik utama dalam Episode Nissa mengenai kencan pertama Miko dengan Anissa. Latar yang ada pada Episode Nissa beragam, yaitu di rumah Miko dan Ryan, di restoran, di mobil, dan terakhir di halaman rumah Anissa. Latar waktunya terjadi pada siang dan malam, terkadang tidak bisa diidentifikasikan jika berada di dalam ruangan yang tidak ada penunjuk waktunya. Partisipan yang turut beraksi dalam episode ini adalah Miko, Ryan, Mas Anca, Anissa dan supir taksi. Dalam Episode Nissa, Maksud film ini secara keseluruhan adalah menceritakan tentang keseharian Miko yang susah mendapatkan pasangan, Ryan yang sok tahu dan Mas Anca yang lugu. Namun cerita ini dikemas secara lucu sehingga tidak membosankan penonton. Maksud khusus dalam episode ini adalah menceritakan pendekatan Miko pada Anissa yang dibantu oleh Ryan. Act sequences berupa bentuk ujaran ada percakapan monolog maupun dialog, bentuk kalimatnya ada deklaratif, interogatif dan eksklamatif. Ragam bahasa yang digunakan tidak resmi. Key yang digunakan berupa santai, tidak santai, bernada tinggi, cuek, canggung, grogi, getir, panik, 
senang, ketakutan, bingung, sedih. Instrumentalities dalam episode ini adalah jalur lisan dengan ragam bahasa tidak resmi. Norma berinteraksi hanya berada pada ruang (jarak pribadi dan sosial) dan pada gerak tubuh. Yang terakhir adalah genre yang berupa percakapan monolog dan percakapan dialog serta percakapan telepon.

Kemudian pada korpus kedua yaitu Hipnotis Vania, didapatkan 19 adegan dan dari 19 adegan ditemukan 122 ujaran. Topik utama dalam episode ini adalah kejahatan dengan cara hipnotis dan pesoalan cinta. Latar tempat dalam episode ini berada di rumah Miko dan Ryan, di café, di lapangan parkir ATM, di mobil, dan di rumah tukang hipnotis. Latar waktunya pada siang dan malam. Lalu ada pula latar waktu yang tidak terindetifikasi karena tidak ada penunjuk waktu, biasanya berada di dalam ruangan. Partisipan dalam episode ini adalah Miko, Ryan, Mas Anca, Vania, Diwaw/Dani, Tukang hipnotis, dan Istri tukang hipnotis. Maksud film ini secara keseluruhan adalah menceritakan tentang keseharian Miko yang susah mendapatkan pasangan, Ryan yang sok tahu dan Mas Anca yang lugu. Namun cerita ini dikemas secara lucu sehingga tidak membosankan penonton. Maksud khusus dalam episode ini adalah menceritakan pendekatan Miko pada Vania, dalam ruang dan waktu yang sama Ryan terkena hipnotis dan Miko bisa menggagalkan hipnotis tersebut secara tidak sengaja. Act sequences dalam episode ini berupa bentuk ujarannya percakapan monolog maupun dialog, bentuk kalimat deklaratif, interogatif dan eksklamatif dan ragam bahasanya tidak resmi. Key yang digunakan dalam episode ini santai, tidak santai, canggung, ramah, angkuh, sopan, sigap, bingung, bersemangat, bernada tinggi, marah, bernada rendah, bingung, emosi, heran, lesu. Instrumentalities pada episode ini berupa jalur lisan dengan ragam bahasa tidak resmi. Norma berinteraksi hanya berada pada ruang (jarak pribadi dan sosial) dan pada gerak tubuh. Genres pada episode ini berupa percakapan monolog dan percakapan dialog.

Dan yang terakhir adalah korpus ketiga yang berjudul Cinta Kucing Melly. Cinta Kucing Melly berjumlah 23 adegan dan di dalamnya terdapat 18 ujaran. Topikutama pada episode ini adalah kecintaan pada hewan yang berlebihan. Latar waktunya pada siang dan malam. Lalu ada pula latar waktu yang tidak terindetifikasi karena tidak ada penunjuk waktu, biasanya berada di dalam ruangan. Latar tempat berada di rumah Miko dan Ryan, di klinik hewan dokter Okto, dan di mobil. Partisipan dalam episode ini adalah Miko, Ryan, Mas Anca, Melly, Gebetan Miko sebelum Melly, Morganissa (kucing), Maemunah, Dokter Okto, Cleo (kucing), dan tiga orang pasien di klinik hewan. Maksud film ini secara keseluruhan adalah menceritakan tentang keseharian Miko yang susah mendapatkan pasangan, Ryan yang sok tahu dan Mas Anca yang lugu. Namun cerita ini dikemas secara lucu sehingga tidak membosankan penonton. Maksud khusus dalam episode ini adalah menceritakan tentang pendekatan Miko pada Melly yang gagal karena Melly lebih suka kucing peliharaan Miko. Act sequences pada episode ini yaitu bentuk ujarannya berupa percakapan monolog maupun dialog, bentuk kalimatnya deklaratif, interogatif, imperatif dan eksklamatif, ragam bahasa yang dipakai tidak resmi. Key yang ditemukan adalah senang, santai, getir, sedih, menangis, sumringah, cuek, kecewa, bernada tinggi, bernada rendah, keki, panik, memaksa, dan memelas. Instrumentalities dalam episode ini berupa jalur lisan dengan ragam bahasa tidakresmi. Norma berinteraksi hanya berada pada ruang (jarak pribadi, sosial dan publik) dan pada gerak tubuh. Genres pada episode ini adalah percakapan monolog, percakapan dialog dan percakapan telepon.

SPEAKING merupakan akronim dari setting and scene, participants, ends, act sequences, key, instrumentalities, norm of interaction and interpretation and genre. Poinpoin ini adalah komponen tutur yang menurut Hymes diperlukan suatututuran guna menjadi satu bentuk peristiwa tutur. Dalam adegan-adegan yang diteliti di Malam Minggu Miko, keseluruhannya merupakan peristiwa tutur karena memenuhi kedelapan komponen 
yang disebutkan di atas. Dalam Setting and scene yang berkaitan dengan latar waktu dan tempat serta situasi, ketiga korpus Malam Minggu Miko, latar tempat yang tidak terganti adalah di rumah Miko dan di mobil. Latar waktu dibagi menjadi dua yaitu siang dan malam, karena pada ketiga korpus, latar waktu susah diidentifikasikan. Latar psikologis atau suasana di tiap adegan beragam sesuai karakter masing-masing pemain. Pada Participants yang berkaitan dengan penutur, lawan tutur dan hal-hal yangberhubungan dengan tuturan. Dalam ketiga korpus serial Malam Minggu Miko yang diteliti, partisipan yang selalu ada di dalam serial adalah Miko, Ryan dan Mas Anca, sementara yang lain berganti sesuai topik pada serial tersebut.

Ends merujuk pada Maksud dan Tujuan. Maksud film ini secara keseluruhanadalah menceritakan tentang keseharian Miko yang susah mendapatkan pasangan, Ryan yang sok tahu dan Mas Anca yang lugu. Namun cerita ini dikemas secara lucu sehingga tidak membosankan penonton. Act sequence yang berkaitan dengan Bentuk dan Isi Ujaran dalam peristiwa tutur merujuk pada bentuk ujaran, bentuk kalimat dan ragam bahasa yang digunakan pada adegan-adegan dalam peristiwa tutur di mockumentary Malam Minggu Miko. Bentuk ujaran yang ditemukan dalam seluruhadegan adalah percakapan, baik itu monolog, dialog maupun telepon. Key berkaitan dengan Cara atau Nada yang digunakan dalam peristiwa tutur.Dalam ketiga korpus, ditemukan banyak sekali cara bertutur termasuk nada tinggi pada saat marah dan nada rendah pada saat sedih, dan sebagainya. Instrumentalities berhubungan dengan bentuk tuturan dan ragam bahasa.

Bentuk tuturan pada tiap korpus Malam Minggu Miko yang diteliti seluruhnya berbentuk jalur lisan. Ragam bahasa yang dipakai keseluruhanpun adalah ragam bahasa tidak resmi. Norm ofinteraction and interpretation mengacu pada norma yang ada pada saat berinteraksi.Norma berinteraksi terbagi menjadi tiga yaitu norma pada ruang, norma pada waktu, dan norma pada gerak tubuh. Norma pada waktu sulit diidentifikasikan karena penanda waktu pada film yang kurang memadai. Norma ruang ditemukan di jarak pribadi dan jarak sosial pada ketiga korpus. Jarak publik hanya ditemukan pada korpus Cinta Kucing Melly. Semetara jarak intim tidak ditemukan di ketiga korpus. Pada gerak tubuh partisipan mengikuti konteks dan suasana. Norma gerak tubuh berhubungan dengan latar suasana.Dan yang terakhir berupa Genre yang berkaitan dengan Jenis atau Bentuk Penyampaian. Keseluruhan korpus Malam Minggu Miko yang diteliti berbentuk percakapan lisan. Di percakapan ini ditemukan lagi tiga jalur berbeda yaitu monolog, dialog dan jalur telepon. Jalur telepon hanya ditemukan pada korpus satu dan ketiga yaitu Anissa dan Cinta Kucing Melly, sementara pada Hipnotis Vania tidak ditemukan jalur telepon.

\section{KESIMPULAN}

Berdasarkan hasil analisis peristiwa tutur dalam mockumentary MalamMinggu Miko, dapat ditarik kesimpulan sebagai berikut: Keseluruhan adegan dalam mockumentary Malam Minggu Miko memenuhi kedelapan syarat untuk menjadi sebuah peristiwa tutur. Dalam Episode Nissa yang menjadi korpus pertama terdapat 14 adegan dengan 135 jumlah ujaran. Topik utamanya mengenai kencan pertama. Kemudian pada episode Hipnotis Vania yang menjadi korpus kedua terdapat 19 adegan dengan 123 jumlah ujaran. Topik utamanya berbicara tentang kejahatan dengan cara hipnotis dan persoalan cinta. Dan terakhir dalam episode Cinta Kucing Melly yang menjadi korpus ketiga terdapat 23 adegan dengan 128 jumlah adegan. Topik utamanya mengenai kecintaan yang berlebihan pada hewan. Pada Setting and Scene terdapat dua latar tempat yang selalu ada pada tiap korpus yang diteliti yaitu di rumah Miko dan Ryan dan di dalam mobil. Dalam Participants terdapat tiga partisipan yang selalu ada pada tiap korpus yang ditelitiyaitu Miko, Ryan dan 
Mas Anca. Persamaan maksud dan tujuan atau ends dari ketiga korpus yang diteliti adalah menceritakan tentang keseharian Miko yang susah mendapatkan pasangan, Ryan yang sok tahu dan Mas Anca yang lugu. Namun cerita ini dikemas secara lucu sehingga tidak membosankan penonton.

Dalam act sequences, persamaan bentuk ujaran pada ketiga korpus yang keseluruhannya berbentuk percakapan monolog maupun dialog. Bentuk kalimat deklaratif, interogatif dan eksklamatif ada pada ketiga korpus namun bentuk kalimat imperatif hanya ada pada korpus Cinta Kucing Melly. Ragam bahasa yang digunakan keseluruhannya adalah ragam bahasa tidak resmi. Terdapat banyak sekali key yang digunakan sehingga bisa dibilang ekspresif dalam tiap korpus data yang diteliti. Piranti bahasa atau Instrumentalities yang digunakan pada keseluruhan adegan dalam tiga korpus berbeda merupakan jalur lisan dengan ragam bahasa yang tidak resmi. Dalam Norm of Interaction and Interpretation, terdapat norma berinteraksi pada ruang yaitu pada jarak pribadi dan sosial di ketiga korpus, namun pada jarak publik hanya ditemukan di korpus ketiga yaitu Cinta Kucing Melly. Gerak tubuh yang dihasilkan sangat ekspresif dalam ketiga korpus. Pada genres atau bentuk penyampaian ditemukan percakapan monolog dan percakapan dialog pada ketiga korpus yang diteliti, namun percakapan telepon hanya ada di dua korpus yaitu episode Nissa dan episode Cinta Kucing Melly.

\section{DAFTAR RUJUKAN}

Chaer, Abdul. Linguistik Umum. 2007. Jakarta: Rineka Cipta.

Chaer, Abdul dan Leonie Agustina. Sosiolinguistik: Perkenalan Awal. 2010. Jakarta: Rhineka Cipta

Effendy, Heru. Mari Membuat Film: Panduan Menjadi Produser. 2006. Yogyakarta: Panduan

Hymes, Dell. Models of the Interaction of Language and Social Life dalamSociolinguistics:The Essential Readings. 1972. USA: Blackwell Publishing LtdIbrahim, Abd. Syukur. Kapita Selekta Sosiolinguistik. 1993. Surabaya: Usaha Nasional

Mahsun, Metode Penelitian Bahasa: Tahapan Strategi, Metode, dan Tekniknya. 2007. Jakarta: PT RajaGrafindo Persada

Pateda, Mansoer. Sosiolinguistik. 1994. Bandung: Angkasa

Pudjiastiti, Puline. Sosiologi. 2007. Jakarta: Grasindo

Rahardi, Kunjana. Kajian Sosiolinguistik Ihwal Kode dan Alih Kode. 2010. Ghalia Indonesia: Bogor

Sumarsono. Sosiolinguistik. 2012. Yogyakarta: Pustaka Pelajar

Verhaar, J.W.M. Asas-Asas Linguistik Umum. 2001. Yogyakarta: Gadjah Mada University Press. 